\title{
PKM Peningkatan Pengetahuan Remaja Putri Mengenai Vulva Hygiene dalam Upaya Promotif dan Preventif di SMP Nurul Jadid
}

\author{
Kholisotin $^{1}$, Inaya Wulandari², Riskiyeh ${ }^{3}$ \\ Universitas Nurul Jadid, Paiton ${ }^{123}$ \\ ayyulfariqoini9@gmail.com, inayaku46@gmail.com, riskiyeh15@gmail.com
}

Submission: 16/08/2021 Received: 14/09/2021 Published: 31/12/2021

\begin{abstract}
Keywords:
teenage girl 1,

vulva hygiene 2 , flour albus 3,

Abstract. Reproductive organs are one of the organs of the body that are sensitive and require special care. Knowledge and good care are the determining factors in maintaining reproductive health. One of the symptoms of abnormalities or disease in the reproductive organs is vaginal discharge. Vaginal discharge is a very common symptom experienced by most women. All women of all ages can experience vaginal discharge. Based on research data on women's reproductive health, it shows that $75 \%$ of women in the world will suffer from vaginal discharge, at least once in their life. More than $70 \%$ of Indonesian women experience vaginal discharge caused by fungi and parasites such as pinworms or protozoa (Trichomonas vaginalis). Purpose of Service: to increase Young Women's Knowledge of Vulvar Hygiene. Service method: identifying student knowledge by giving questionnaires before and after health counseling.
\end{abstract}

Katakunci:

Remaja putri 1, Vulva hygiene 2 , keputihan 3,
Abstrak. Organ reproduksi merupakan salah satu organ tubuh yang sensitif dan memerlukan perawatan khusus. Pengetahuan dan perawatan yang baik merupakan faktor penentu dalam memelihara kesehatan reproduksi. Salah satu gejala terjadinya kelainan atau penyakit pada organ reproduksi adalah Keputihan. Berdasarkan data penelitian tentang kesehatan reproduksi wanita menunjukkan 75\% wanita di dunia pasti menderita keputihan, paling tidak sekali dalam hidupnya. Sedangkan wanita Indonesia sendiri 75\% pasti mengalami keputihan minimal satu kali dalam hidupnya. Lebih dari $70 \%$ wanita Indonesia mengalami keputihan yang disebabkan oleh jamur dan parasit seperti cacing kremi atau protozoa (Trichomonas vaginalis).Tujuan Pengabdian: untuk meningkatkan Pengetahuan Remaja Putri Mengenai Vulva Hygiene. Metode pengabdian: mengidentifikasi pengetahuan siswi dengan memberikan kuesioner sebelum dan sesudah dilakukan penyuluhan kesehatan. 


\section{Pendahuluan}

Kesehatan reproduksi merupakan suatu kondisi atau keadaan sehat secara menyeluruh baik kesejahteraan fisik, mental dan sosial yang utuh dalam segala hal yang berkaitan dengan fungsi, peran dan proses reproduksi yang dimiliki oleh remaja (Bayang, 2016).

Membersihkan organ kewanitaan (vulva hygiene) bagian luar penting untuk dilakukan oleh setiap wanita untuk mencegah terjadinya infeksi dan penyakit kelamin (Humairoh, 2018). Perilaku vulva hygiene yang baik dan benar menjadi salah satu kunci peningkatan kesehatan reproduksi seorang wanita.

Pengetahuan tentang kesehatan reproduksi yang rendah akan memungkinkan perempuan tidak menjaga Hygiene saat menstruasi, hal itu dapat membahayakan kesehatan reproduksi remaja seperti timbulnya penyakit kelamin, penyakit infeksi saluran kemih, keputihan, dan iritasi kulit genital (Anggraeni et al,. 2018). Kurangnya pengetahuan tentang Vulva hygiene ini banyak dialami oleh remaja yang baru mengalami masa awal menstruasi (Menarche) (Humairoh, 2018).

Keputihan atau fluor albus merupakan cairan yang keluarkan dari alat genital perempuan. Keputihan atau fluor albus paling sering dijumpai pada penderita genekologi, adanya gejala ini diketahui penderita kurang menjaga kebersihan vaginanya. Keputihan dapat dibedakan antara keputihan yang bersifat fisiologis dan patologis, Keputihan fisiologis terdiri atas cairan yang kadang-kadang berupa mukus yang mengandung banyak epitel dengan leukosit yang jarang sedangkan pada Keputihan yang patologis terdapat banyak leukosit (Sarwono, 2009). Keputihan merupakan masalah yang cukup serius dialami wanita, keputihan tidak menyebabkan kanker, namun merupakan salah satu gejala kanker serviks. (Boyke, 2008).

Kebersihan daerah genetalia terutama pada saat menstruasi sering diabaikan oleh wanita. Pada saat menstruasi darah dan keringat keluar serta menempel pada vulva dapat menyebabkan daerah genetalia menjadi lembab. Menurut survey Departemen Kesehatan Jawa Barat tahun 2011 sekitar 316 orang mengalami infeksi pada genetalia eksternal, dan 592 orang mengalami keputihan pada remaja putri. Rendahnya pengetahuan tentang kesehatan reproduki akan memungkinkan perempuan tidak berperilaku 
hygiene pada saat menstruasi yang dapat membahayakan kesehatan reproduksinya sendiri. Kebersihan daerah genetalia terutama pada saat menstruasi sering diabaikan oleh wanita. Pada saat menstruasi darah dan keringat keluar serta menempel pada vulva dapat menyebabkan daerah genetalia menjadi lembab. Jika pada saat itu tidak menjaga kebersihan genetalia dengan benar, maka dalam keadaan lembab, jamur dan bakteri yang berada di daerah genetalia akan tumbuh subur sehingga menyebabkan rasa gatal dan infeksi pada daerah tersebut. Infeksi yang diabaikan oleh hygiene yang buruk selama menstruasi yang sering terjadi pada wanita yaitu, keputihan, vaginitis bacterial, trichomonas vaginalis, kandidiasis vulvovginitis dan sebagainya. Bila infeksi tersebut dibiarkan dan tidak diobati dengan sempurna, akan menimbulkan infeksi yang merambat ke organ reproduksi bagian dalam seperti radang panggul (Prawirohardjo, 2009).

Vulva hygiene saat menstruasi kemungkinan besar dipengaruhi oleh tingkat pengetahuan tentang kesehatan reproduksi (Indriastuti, 2009). Rendahnya pengetahuan tentang kesehatan reproduki akan memungkinkan perempuan tidak berperilaku hygiene pada saat menstruasi yang dapat membahayakan kesehatan reproduksinya sendiri (BKKBN, 2011). Hygiene menstruasi merupakan komponen hygiene perorangan yang memegang peran penting dalam menentukan status kesehatan, khususnya terhindar dari infeksi alat reproduksi, oleh karena itu pada saat menstruasi perempuan harus benar-benar menjaga kebersihan organ reproduksi secara ekstra terutama pada bagian vagina apabila tidak dijaga akan menimbulkan mikroorganisme seperti jamur, bakteri dan virus yang berlebihan sehingga menganggu fungsi organ reproduksi (Indriastuti, 2009).

Perawatan organ-organ reproduksi sangatlah penting. Jika tidak dirawat dengan benar dapat menyebabkan berbagai macam akibat yang dapat merugikan, misalnya infeksi dan penyakit kelamin seperti ISR, ISK, vaginitis, keputihan (Kusmiran, 2011).

Alat genital wanita terdapat mekanisme pertahanan tubuh berupa bakteri yang menjaga kadar keasaman $\mathrm{pH}$ vagina. Normalnya angka keasaman pada vagina berkisar antara 3,8-4,2. Sebagian besar, hingga 95\% adalah bakteri laktobasilus dan selebihnya adalah bakteri patogen. Data penelitian tentang kesehatan reproduksi wanita menunjukkan 75\% wanita didunia pasti 
menderita keputihan, paling tidak sekali seumur hidup dan 45\% diantaranya mengalami keputihan sebanyak dua kali atau lebih (Pribakti, 2008).

Kebersihan perorangan atau personal hygiene merupakan suatu tindakan untuk memelihara kebersihan dan kesehatan seseorang untuk menjaga kesejahteraan fisik dan psikis. Salah satu dampak kurang dari menjaga personal hygine adalah terjadinya keputihan. (Izzati and Agustiani 2014)

Keputihan merupakan permasalahan yang sudah menjadi persoalan dan pembahasan sejak lama bagi kaum perempuan pada umumnya. Hal ini dikarenakan dari berbagai usia perempuan dapat mengalami kejadian keputihan. Terlebih pada remaja putri yang cenderung belum memahami bagaimana cara merawat organ kewanitaan dengan baik. Dengan demikian, remaja putri merupakan masa peralihan yang sangat berisiko untuk mengalami kejadian keputihan dan harus menjadi perhatian khusus dari praktisi kesehatan. Praktisi kesehatan sebaiknya meperhatikan kondisi remaja putri yang sedang dalam masa peralihan dikarenakan apabila keputihan tidak dipedulikan atau ditangani dengan baik, keputihan dapat yang dapat berakibat fatal. Permasalahan yang ditimbulkan dapat berupa kemandulan atau kehamilan di luar uterus. Hal yang lebih berbahaya lagi yang mengancam kaum wanita adalah bahwa keputihan dapat berupa gejala awal kanker serviks. Sudah diketahui bahwa kanker serviks merupakan penyebab kematian nomor satu pada wanita. Hal hal yang dapat dilakukan adalah dengan melakukan penyuluhan.

Dampak yang bisa terjadi bila tidak menjaga kebersihan alat reproduksi yaitu bisa terkena jamur atau kutu yang dapat menyebabkan rasa gatal dan tidak nyaman, mencuci atau membersihkan daerah genital dengan air kotor, pemeliharaan yang tidak benar dapat menyebabkan keputihan yang abnormal dan resiko terjadinya kanker rahim (Astuti, Dewi, and Widiastuti 2016).

Personal hygiene saat menstruasi dapat dilakukan dengan cara mengganti pembalut setiap 4 jam sekali atau 3 sampai 4 kali dalam sehari. Setelah mandi atau buang air, membasuh vagina dengan arah depan kebelakang anus, vagina dikeringkan dengan tisu atau handuk agar tidak lembab. Pemakaian celana dalam yang baik terbuat dari bahan yang mudah menyerap keringat (Elmart, 2012). 
Salah satu peran penting perawat adalah sebagai health educator, seorang perawat dalam melakukan perannya sebagai educator yaitu mendidik individu, keluarga, kelompok dan masyarakat serta tenaga kesehatan. Perawat sebagai Educator atau pendidik adalah membantu klien dalam meningkatkan tingkat pengetahuan kesehatan, gejala penyakit bahkan tindakan yang diberikan, sehingga terjadi perubahan perilaku dari klien setelah dilakukan pendidikan kesehatan (Diana, 2012).

Salah satu peran penting perawat adalah sebagai educator, yaitu perawat sebagai pendidik, mendidik individu, keluarga, kelompok serta masyarakat dan tenaga kesahatan. Perawat sebagai Health Educator yang bertujuan untuk membantu klien khususnya remaja dalam meningkatkan pengetahuan tentang kesehatan, tentang penyakit, bahkan tindakan yang akan diberikan, sehingga terjadi perubahan perilaku klien setelah diberikannya Health Education tersebut, yang dalam hal ini adalah vulva hygiene saat menstruasi (Maidartati et al., 2016).

hygiene perorangan yang memegang peran penting dalam menentukan status kesehatan, khususnya terhindar dari infeksi alat reproduksi, oleh karena itu pada saat menstruasi perempuan harus benar-benar menjaga kebersihan organ reproduksi secara ekstra terutama pada bagian vagina apabila tidak dijaga akan menimbulkan mikroorganisme seperti jamur, bakteri dan virus yang berlebihan sehingga menganggu fungsi organ reproduksi (Indriastuti, 2009).

Semua wanita dengan segala umur dapat mengalami keputihan. Berdasarkan data penelitian tentang kesehatan reproduksi wanita menunjukkan 75\% wanita di dunia pasti menderita keputihan, paling tidak sekali dalam hidupnya. Sedangkan wanita Indonesia sendiri 75\% pasti mengalami keputihan minimal satu kali dalam hidupnya. Gejala keputihan juga banyak dialami oleh wanita yang belum menikah atau remaja puteri yang berumur 15-24 tahun yaitu sekitar 31,8\%. Lebih dari 70\% wanita Indonesia mengalami keputihan yang disebabkan oleh jamur dan parasit seperti cacing kremi atau protozoa (Trichomonas vaginalis) (Lipsky,2011). Angka ini berbeda tajam dengan Eropa yang hanya 25\% saja karena cuaca di Indonesia yang lembab sehingga mudah terinfeksi jamur Candida albicans yang merupakan salah satu penyebab keputihan (Febiliawanti,2011). 
Vulva hygiene adalah membersihkan vulva dan daerah sekitarnya pada pasien wanita yang sedang nifas atau tidak dapat melakukannya sendiri. Pasien yang harus istirahat di tempat tidur (misalnya, karena hipertensi, pemberian infus, section caesarea) harus dimandikan setiap hari dengan pencucian daerah perineum yang dilakukan dua kali sehari dan pada waktu sesudah selesai membuang hajat. Meskipun ibu yang akan bersalin biasanya masih muda dan sehat, daerah daerah yang tertekan tetap memerlukan perhatian serta perawatan protektif.

Jamur dan bakteri banyak tumbuh dalam kondisi tidak bersih dan lembab. Organ reproduksi merupakan daerah tertutup dan berlipat, sehingga lebih mudah untuk berkeringat, lembab dan kotor (Suparyanto,2011). Perilaku buruk dalam menjaga kebersihan genitalia, seperti mencucinya dengan air kotor, memakai pembilas secara berlebihan, menggunakan celana yang tidak menyerap keringat, jarang mengganti celana dalam, tidak sering mengganti pembalut dapat menjadi pencetus timbulnya infeksi yang menyebabkan keputihan tersebut. Oleh karnanya pengetahuan dan perilaku dalam menjaga kebersihan genitalia eksterna merupakan faktor penting dalam pencegahan keputihan (Ratna, 2010).

Kesehatan reproduksi remaja khususnya wanita terutama dalam menjaga dan merawat organ reproduksi dipengaruhi oleh pengetahuan orang tua, tingkat pendidikan orang tua, dan peran orang tua terutama ibu dalam memberikan pendidikan kesehatan reproduksi sehingga remaja putri dapat mengetahui dan merawat organ reproduksi, akan tetapi orang tua merasa tidak nyaman membicarakan masalah seksual (Widyastuti, 2009). Minimnya komunikasi antara orang tua dan remaja mengenai kesehatan reproduksi dapat mengakibatkan kurangnya informasi tentang kesehatan reproduksi tersebut secara benar (Gowanda, 2007). Hal itu terbukti dari banyak penelitian menyatakan rendahnya tingkat pengetahuan mengenai kebersihan organ genitalia para remaja Putri.

Kebersihan merupakan hal yang sangat penting dan harus diperhatikan karena kebersihan akan mempengaruhi kesehatan dan perilaku seseorang. vulva hygiene adalah suatu tindakan untuk memelihara kebersihan dan kesehatan seseorang, untuk menjaga kesejahteraan fisik dan psikis (Isro'in, 2012). Untuk itu tenaga kesehatan mempunyai peranan penting dalam 
mendidik masyarakat tentang pentingnya vulva hygiene yang baik dalam mencegah keputihan melalui penyuluhan kesehatan.

Menjaga kesehatan berawal dari menjaga kebersihan. Hal ini juga berlaku bagi kesehatan organ-organ seksual. Cara memelihara organ intim tanpa kuman dilakukan sehari-hari dimalai bangun tidur dan mandi pagi. Alat reproduksi dapat terkena sejenis jamur atau kutu yang dapat menyebabkan rasa gatal atau tidak nyaman apabila tidak dirawat kebersihannya. Mencuci vagina dengan air kotor, pemeriksaan dalam yang tidak benar, penggunaan pembilas vagina yang berlebihan, pemeriksaan yang tidak higienis, dan adanya benda asing dalam vagina dapat menyebabkan keputihan yang abnormal. Keputihan juga bisa timbul karena pengobatan abnormal, celana yang tidak menyerap keringat (Eni, 2011).

Menurut Elmart (2012) Upaya kebersihan diri yang terkait organ reproduksi yaitu vulva hygiene. Vulva hygiene sendiri terdiri dari atas dua kata, yaitu vulva atau kelamin luar, dan hygiene yang berarti kebersihan. Jadi vulva hygiene itu mencakup cara menjaga dan merawat kebersihan organ kelamin bagian luar. Berikut beberapa hal yang harus diperhatikan terkait kebersihan organ luar wanita (Elmart, 2012).

Menurut lestariningsih (2015) internet saat ini sangat berperan penting dalam mengangkat masalah kesehatan seperti hygiene saat mesntruasi. Iklan yang yang terdapat dalam internet seperti iklan tentang pembalut wanita ataupun obat-obatan yang berhubungan dengan reproduksi akan selalu muncul di internet, secara tidak langsung semua kalangan akan bisa mengakses informasi tersebut (Anjan \& Susanti, 2019).

Periode usia remaja awal umumnya masih awam terhadap konsep Kesehatan reproduksi. Pendidikan kesehatan repoduksi pada remaja usia dini sangat penting sebagai pemahaman dasar dalam menjaga kesehatan reproduksi (Hasanah, 2016). Pemahaman dasar tersebut dapat diperoleh dari orang tua, guru, teman sebaya, dan

Pengetahuan dipengaruhi oleh beberapa faktor salah satunya usia. Usia menggambarkan kematangan fisik, kematangan psikis dan sosial yang dapat mempengaruhi proses belajar remaja. Usia menjadi salah satu faktor yang mempengaruhi penangkapan informasi atau pengetahuan yang pada 
akhirnya akan mempengaruhi tingkat pengetahuan remaja itu sendiri (Hanifah \& Sri, 2017).

Usia awal menstruasi berhubungan sekali dengan pengetahuan dan pengalaman saat menstruasi dan hal tersebut akan berpengaruh pada perilaku perawatan diri saat menstruasi (Solehati et al., 2017).

Berdasarkan hasil studi pendahuluan yang dilakukan di bulan januari 2021 dari 10 siswi SMP Nurul Jadid.

\section{Metode}

Alat yang digunakan pada kegiatan Pengabdian Masyarakat ini adalah infokus, laptop, kuesioner, SAP Penyuluhan, Manekin dan alat tulis, Camera. Kegiatan ini dilakukan pada bulan Februari 2021. Adapun kegiatan Pengabdian Masyarakat yang dilakukan adalah:

\section{Tahap I}

a. Melakukan studi pendahuluan dan wawancara dengan Guru dan Siswi kelas VII SMP Nurul Jadid

b. Menjelaskan maksud kedatangan ke sekolah untuk melakukan penyuluhan Tentang vulva hygiene

c. Mengurus Perizinan Pengabdian Masyarakat

d. Membagikan kusioner kepada siswi sebelum penyuluhan tentang vulva hygiene

e. Melakukan Penyuluhan tentang vulva hygiene

f. Mempraktikkan vulva hygiene yang benar

g. Membuka sesi tanya jawab bagi siswi berdasarkan materi yang disampaikan

h. Menyediakan reward (hadiah) bagi siswi yang mengajukan pertanyaan atau yang menjawab pertanyaan dari pemateri

i. Membagikan kusioner kepada siswi sesudah penyuluhan tentang vulva hygiene

j. Membagikan leafleat Penyuluhan

k. Melakukan Dokumentasi kegiatan penyuluhan

I. Mendata jumlah peserta (siswi) yang hadir 


\section{Tahap II}

Tahapan kedua dilakukan untuk menilai dan menganalisa hasil dari penyuluhan terhadap Siswi kelas VII SMP Nurul Jadid:

a. Mengidentifikasi pengetahuan Siswi kelas VII SMP Nurul Jadid sebelum diberikan penyuluhan tentang vulva hygiene dengan menggunakan kuesioner.

b. Mengidentifikasi pengetahuan Siswi kelas VII SMP Nurul Jadid sesudah diberikan penyuluhan tentang vulva hygiene dengan menggunakan kuesioner.

c. Menganalisa pengaruh penyuluhan tentang vulva hygiene terhadap tingkat pengetahuan Siswi kelas VII SMP Nurul Jadid

\section{Hasil dan Pembahasan}

\section{Hasil}

Kegiatan pengabdian Masyarakat ini adalah memberikan penyuluhan pada Siswi kelas VII smp nurul jadid dan melibatkan beberapa Guru SMP Nurul Jadid. Pada saat dilakukan penyuluhan tersebut siswi kelas VII smp nurul jadid terlihat fokus dalam mendengarkan materi yang disampaikan, mereka mengatakan bahwa baru pertama kali mendapatkan materi tentang vulva hygiene. Sehingga banyak siswi kelas VII smp nurul jadid mengetahui tentang pencegahan keputihan yang sering terjadi pada remaja putri dengan melakukan vulva hygiene yang benar. Setelah narasumber selesai menyampaikan materi, banyak siswi ingin mengajukan pertanyaan namun karena keterbatasan waktu, hanya beberapa siswi yang mendapatkan kesempatan bertanya. Begitu juga ketika sesi tanya jawab, seluruh siswi dapat menjawab pertanyaan yang diberikan oleh narasumber.

Berdasarkan hasil penilaian kusioner yang diberikan kepada Siswi kelas VII SMP Nurul Jadid sebanyak sebelum dan sesudah diberikan Penyuluhan tentang vulva hygiene, $99 \%$ Siswi kelas VII SMP Nurul Jadid mengalami peningkatan pengetahuan setelah diberikan penyuluhan. 


\begin{tabular}{|l|l|c|c|c|c|}
\hline \multirow{2}{*}{ No } & \multirow{2}{*}{$\begin{array}{c}\text { Tingkat } \\
\text { Pengetahuan }\end{array}$} & \multicolumn{2}{|c|}{ Sebelum Penyuluhan } & \multicolumn{2}{c|}{ Setelah Penyuluhan } \\
\cline { 3 - 6 } & Jumlah & $\%$ & Jumlah & $\%$ \\
\hline 1. & baik & 16 & 23 & 69 & 99 \\
\hline 2. & kurang & 54 & 77 & 1 & 1 \\
\hline \multicolumn{2}{r}{ Jumlah } & 70 & 100 & 70 & 100 \\
\hline
\end{tabular}

Berdasarkan Tabel. 1 Tingkat pengatuhuan siswi SMP Nurul Jadid sebelum diberikan penyuluhan kesehatan mempunyai tingkat Pengetahuan Rendah sebanyak 54 siswi (77\%). Setelah diberikan penyuluhan kesehatan Siswi SMP Nurul Jadid mempunyai tingkat Pengetahuan baik sebanyak 69 Siswi (99\%). Dalam kegiatan Pengabdian Masyarakat Penyuluhan Kesehatan Vulva Hygiene pada siswi SMP Nurul Jadid dalam upaya promotif dan preventif.

\section{a. Pembahasan}

Sebelum dilakukannya penyuluhan pada siswi SMP Nurul Jadid tingkat pengetahuan kurang sebanyak 54 siswi (77\%) dan pengetahuan baik sebanyak 69 siswi (99\%). Setelah diberikan penyuluhan kesehatan tingkat pengetahuan siswi SMP nurul jadid meningkat sebanyak 69 siswi (99\%) berada dalam kategori baik dan 1 (\%) siswi mempunyai pengetahuan kurang. Hal ini menunjukkan pendidikan kesehatan yang diberikan kepada siswi SMP nurul Jadid memberikan

Pengukuran pengetahuan dapat dilakukan dengan wawancara atau angket yang menanyakan tentang isi materi yang ingin diukur dari subyek penelitian atau responden. Kedalaman pengetahuan yang ingin kita ketahui atau kita ukur dapat kita sesuaikan dengan tingkat-tingkat tersebut diatas. Individu mempunyai dorongan untuk ingin mengerti dengan pengalamapengalamannya. Ini berarti bila seseorang mempunyai sikap tertentu terhadap suatu objek, menunjukkan tentang pengetahuan orang terhadap objek sikap yang bersangkutan.

Penyuluhan pada umumnya semakin tinggi penyuluhan seseorang maka semakin tinggi pula tingkat pengetahuan. Penyuluhan itu sendiri adalah bimbingan yang diberikan oleh seseorang terhadap perkembangan orang lain menuju kea rah suatu cita-cita tertentu. 
Hal ini sejalan dengan penelitian yang di lakukan kholisotin 2020 dengan judul "Pengaruh Paket edukasi HbsAg terhadap pengetahuan dan sikap ibu hamil trisemester 1 tentang $\mathrm{HbsAg}^{\prime}$ dari hasil penelitian didapatkan nilai pevalue 0,00 $<0,05$ yang berarti ada perbedaan pengetahuan dan sikap ibu hamil trimester 1 tengtang $\mathrm{HbsAg}$ sebelum dan sesudah di berikan intervensi

Pengetahuan adalah segala apa yang di ketahui berdasarkan pengalaman yang didapatkan oleh setiap manusia. Pengetahuan merupakan hasil mengingat suatu hal, termasuk mengingat Kembali kejadian yang pernah dialami baik secara sengaja maupun tidak disengaja dan ini terjadi setelah orang melakukan kontak atau pengamatan terhadap suatu objek tertentu.

Seseorang berpengetahuan baik tidak menjamin akan mempunyai sikap dan perilaku yang positif. karena seseorang dalam menentukan sikap dan perilaku yang utuh selain ditentukan oleh pengetahuan, juga dipengaruhi oleh pikiran, keyakinan dan emosi yang memegang peranan penting. (Notoadmodjo, 2010).

Pengetahuan atau kognitif merupakan domain yang sangat penting dalam membentuk Tindakan seseorang (overtbehavior). Karena dari pengalaman dan penelitian ternyata perilaku yang didasari pengetahuan akan lebih langgeng daripada perilaku yang tidak didasari oleh pengetahuan. Tingkat pengetahuan yang kurang, sikap negatif maupun keterampilan yang kurang juga dapat dipengaruhi oleh factor yang lain misalnya informasi yang diberikan sebelumnya mencakup media, materi, maupun Pendidikan, factor tersebut dapat mempengaruhi bagaimana seseorang dapat menerima informasi dan dapat mengingat Kembali informasi yang telah di dapat.

Pengetahuan adalah hasil dari tahu yang terjadi setelah seseorang melakukan penginderaan terhadap suatu objek tertentu. Penginderaan terjadi melalui panca indera manusia yaitu penciuman, penglihatan, pendengaran, perasaan, dan berabaan. Sebagian besar penginderaan diperoleh dari mata dan telinga. Pengetahuan umumnya dating dari pengalaman dan informasi yang disampaikan guru, orang tua, teman dan media massa.

Menurut notoatmodjo sikap merupakan konsep paling penting dalam psikologi social yang membahas unsur sikap baik sabagai individu maupun 
kelompok. Banyak kajian dilakukan untuk merumuskan pengertian sikap, proses terbentuknya sikap maupun perubahan. Banyak pula penelitian telah dilakukan terhadap sikap kaitannya dengan efek dan perannya dalam pembentukan karakter dan system hubungan antar kelompok serta pilihanpilihan yang ditentukan berdasarkan lingkungan dan pengaruhnya terhadap perubahan. Reaksi seseorang dapat menunjukkan ksiapan untuk bereaksi terhadap stimulus tertentu. Terbentuknya sikap dipengaruhi sikap orang lain dengan ekspresinya sering pula sikap tersebut dipengaruhi oleh pembicaraan orang lain, setelah pengenalan lebih dalam, pengetahuan yang lebih luas mungkin akan merubah sikap atau menetap dan sikap itu baru berubah setelah ada pemahaman.

Sebagaimana yang disampaikan notoatmodjo bahwa salah satu cara yang dapat dilaksanakan untuk mempengaruhi perilaku Kesehatan individu, kelompok atau suatu masyarakat dapat melalui Pendidikan Kesehatan. Penyuluhan Kesehatan merupakan salah satu media dalam Pendidikan Kesehatan. Penyuluhan memang di anggap mampu meningkatkan pengetahuan dan juga sikap peserta yang mengikutinya

Menurut notoatmodjo (2014) bahwa manusia mempelajari kelakuan dari orang lain di lingkungan sosialnya, Pengetahuan seseorang dipengaruhi oleh factor internal dan factor eksternal yaitu di antaranya tingkat kecerdasan, tingkat emosional, Pendidikan, lingkungan, social budaya, atau tingkat ekonomi masing-masing. Dari pengetahuan tersebut dapat di ambil, dipahami, diaplikasikan, dianalisis, disintesis, dan kemudian dapat di evaluasikan dengan cara pemahaman masing-masing.

Notoatmodjo mengatakan terbentuknya suatu perilaku baru, terutama pada orang dewasa dimulai pada domain kognitif, dalam arti subjek terlebih dahulu terhadap stimulus yang berupa materi atau objek luarnya, menimbulkan respon batin dalam bentuk sikap, selanjutnya menimbulkan respon lebih jauh lagi berupa Tindakan. Perilaku yang didasari oleh pengetahuan, kesadaran dan sikap positif akan bersifat langgeng. Komponen kognitif merupakan aspek kecenderungan berperilaku tertentu sesuai sikap yang dimiliki oleh seseorang. Aspek ini berisi terdensi kecenderungan untuk bertindak atau bereaksi terhadap sesuatu dengan cara-cara tertentu.

Menurut teori diatas dapat disimpulkan bahwa pengetahuan adalah informasi yang dapat merubah seseorang atau sesuatu, dimana pengetahuan 
itu menjadi dasar dalam bertindak, atau pengetahuan itu menjadi seorang individu memiliki kecakapan dalam melakukan Tindakan yang benar.

kognitif atau pengetahuan seseorang sangat berpengaruh sekali dalam membentuk tindakan seseorang. Berdasarkan pengalaman, perilaku yang didasari oleh pengetahuan akan lebih lama diingat dibandingkan perilaku yang tanpa didasari oleh pengetahuan (Hanifah \& Sri, 2017).

Perilaku seseorang ditentukan oleh pengetahuan, kepercayaan individu, sikap seseorang terhadap stimulus atau suatu objek tertentu, dan pengaruh lingkungan sekitar. Dukungan lingkungan sekitar dapat mempengaruhi remaja dalam upaya membentuk identitas diri, dan lingkungan sekitar juga bisa menjadi sumber informasi remaja terkait dengan hal-hal yang dialaminya (Suryani, 2019). Kurang baiknya perilaku kesehatan remaja dapat disebabkan oleh kurangnya informasi yang didapakan remaja, dimana informasi yang seharusnya didapatkan dari orang tua, tetapi informasi tersebut tidak didapatkan oleh remaja, sehingga menyebabkan perilaku yang tidak didasari oleh pengetahuan yang cukup (Ristraningsih, 2017).

Prof. Dr. M. J. Langevelt, Pendidikan adalah setiap usaha, pengaruh, perlindungan, dan bantuan yang di lakukan untuk menjadi dewasa. Ciri orang dewasa di tunjukkan oleh kemampuan cara fisik, mental, moral, social, dan emosional. Berdasarkan GBHEN (garis-garis besar negara), Pendidikan adalah usaha sadar untuk mengembangkan kepribadian dan kemampuan dalam dan diluar sekolah yang berlangsung seumur hidup.

Menurut notoatmodjo (2003), Pendidikan secara umum adalah segala upaya yang direncanakan untuk memengaruhi orang lain sehingga mereka melakukan apa yang di harapkan oleh pelaku Pendidikan. Pengertian tersebut mengandung 3 unsur Pendidikan yang meliput input (sasaran dan pelaku), proses (upaya yang direncanakan), dan output (perilaku yang diharapkan). Dari beberapa pendapat tersebut, disimpulkan bahwa Pendidikan pada dasarnya adalah segala upaya yang terencana untuk memengaruhi, memberikan perlindungan dan bantuan sehingga peserta memiliki memampuan untuk berperilalu sesuai harapan.

Dewasa ini masih banyak dijumpai penyakit-penyakit infeksi yang mengganggu alat reproduksi (alat kelamin/genetalia) wanita. Sehingga untuk 
menjaga alat kelamin pada wanita penekanannya pada bagaimana cara melakukan vulva hygiene dengan baik dan benar untuk dapat menghindari bahaya infeksi alat reproduksi. Karena, masalah infeksi mempunyai akibat yang buruk pada kesehatan reproduksi wanita yang berakhir dengan infertilitas (kemandulan) dan meningkatkan kejadian kehamilan ektopik atau hamil di luar kanduntuk memelihara kebersihan organ kewanitaan bagian luar (vulva) yang dilakukan untuk mempertahankan kesehatan dan mencegah infeksi (Ayu, 2010). Pada usia remaja menganggap hal tersebut tidak penting karena mereka tidak tahu dampak yang akan ditimbulkan jika Vulva hygiene tidak dilakukan dengan benar, terutama saat mengalami keputihan.

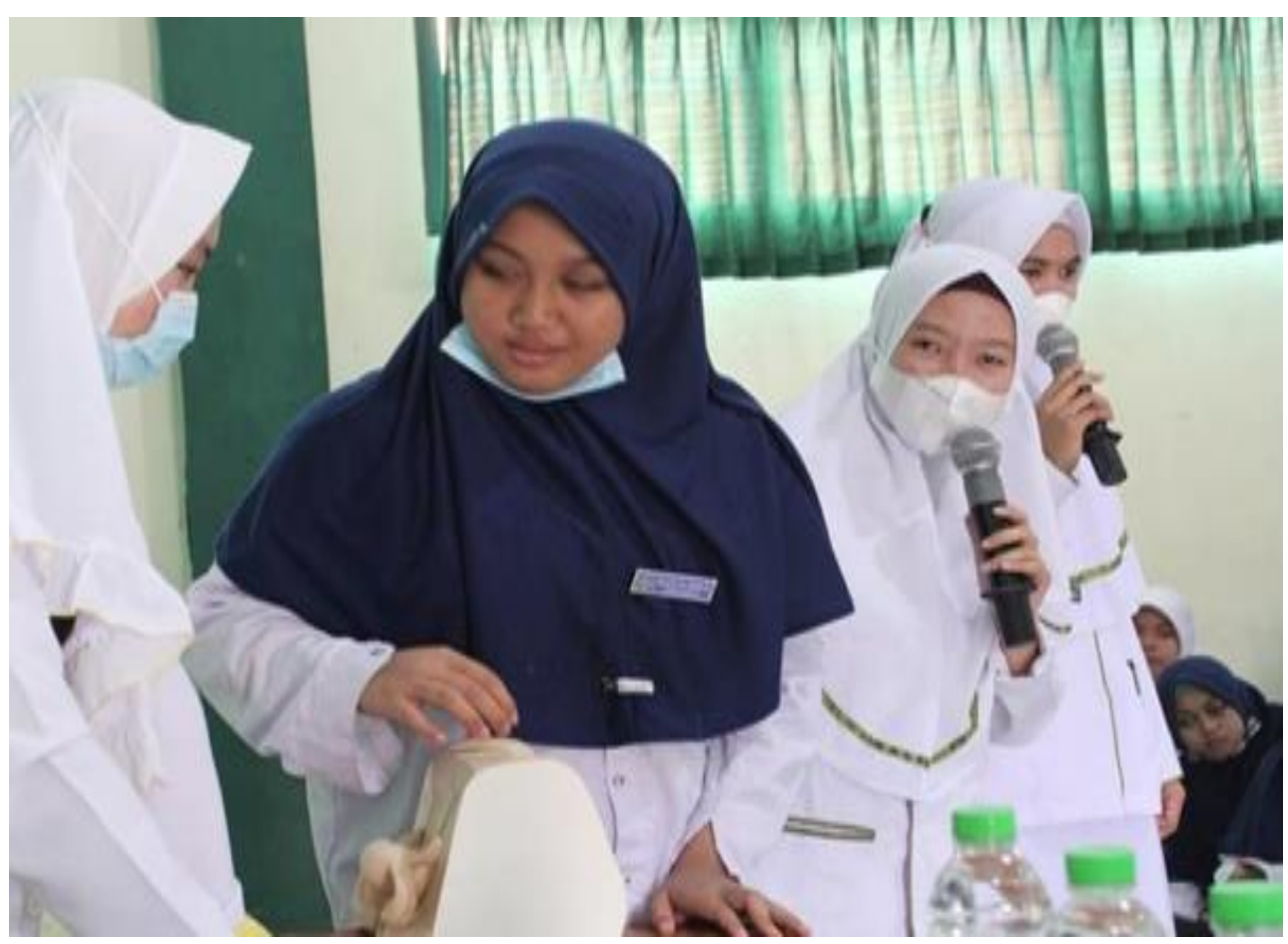

Menjaga kesehatan berawal dari menjaga kebersihan. Hal ini juga berlaku bagi kesehatan organ-organ seksual. Cara memelihara organ intim tanpa kuman dilakukan dalam sehari-hari dimulai dari bangun tidur dan mandi pagi. Alat reproduksi dapat terkena sejenis jamur atau kutu yang dapat menyebabkan rasa gatal atau tidak nyaman apabila tidak jaga kebersihannya. Mencuci vagina dengan air kotor, pemeriksaan dalam yang tidak benar, pemeriksaan yang tidak higienis, dan adanya benda asing dalam vagina dapat menyebabkan keputihan yang abnormal. Keputihan juga dapat timbul 
apabila memakai celana dalam yang tidak menyerap keringat, dan terkena penyakit menular seksual (Kusmiran, 2011).

Salah satu upaya dalam pemeliharaan dan perawatan genetalia dengan penyuluhan kesehatan. Karena, semakin banyak informasi dapat mempengaruhi atau menambah pengetahuan seseorang dan pengetahuan menimbulkan kesadaran yang akhirnya akan mengubah perilaku seseorang sesuai pengetahuannya (Notoatmodjo, 2010).

Pendidikan secara umum adalah segala upaya yang direncanakan memperngaruhi orang lain baik indiviidu, kelompok atau masyarakat. Pendidikan Kesehatan ditujukan untuk mengunggah kesadaran, memberikan atau meningkatkan pengetahuan masyarakat tentang pemeliharaan dan peningkatan Kesehatan bagi dirinya sendiri, keluarga atau masyarakat (notoatmodjo, 2014).

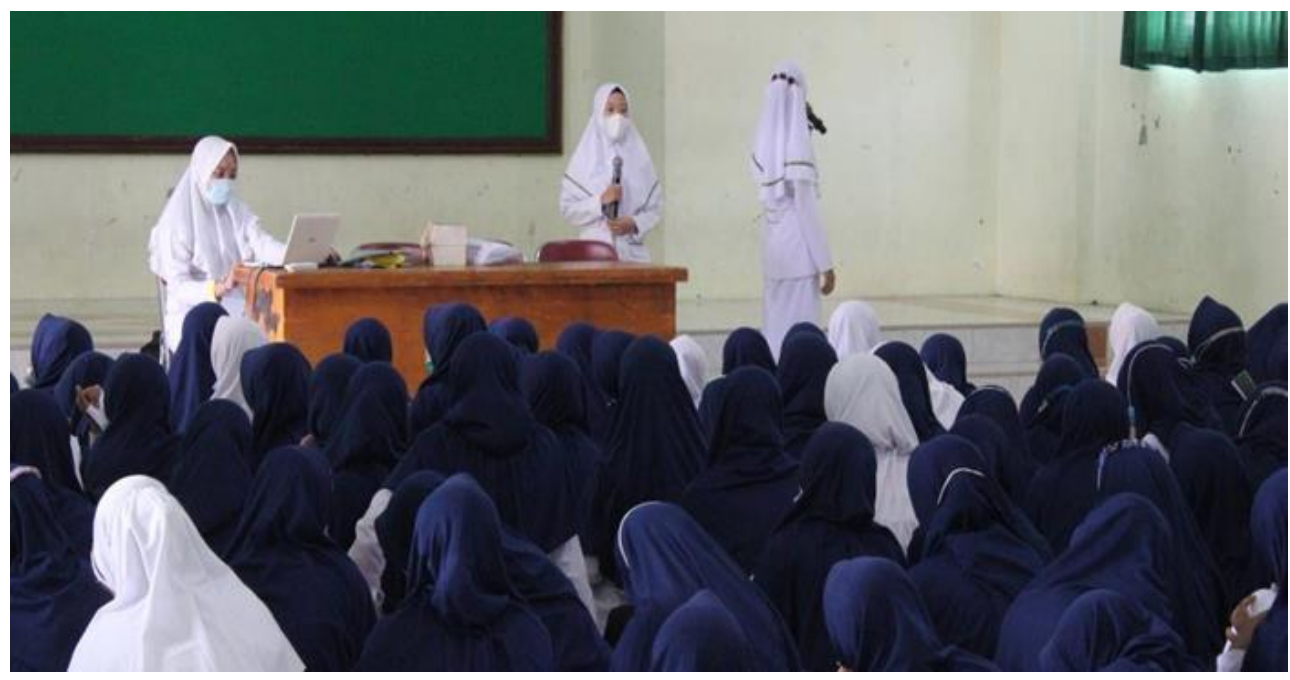

Pendidikan kesehatan merupakan proses perubahan perilaku secara terencana pada diri individu, kelompok, atau masyarakat untuk dapat lebih mandiri dalam mencapai tujuan hidup sehat. Kerena pendidikan kesehatan merupakan proses belajar pada individu, kelompok, atau masyarakat dari tidak tahu tentang nilai kesehatan menjadi tahu, dan dari tidak mampu mengatasi masalah kesehatan sendiri menjadi mandiri (Suliha, 2009).

Sedangkan Menurut Ronald (2011), pendidikan kesehatan merupakan suatu bentuk intervensi yang mandiri untuk membantu klien baik individu, keluarga, kelompok maupun masyarakat dalam mengatasi masalah kesehatannya melalui pemberian informasi secara langsung dengan demikian 
pendidikan kesehatan dapat meningkatkan pengetahuan dan keterampilan siswi SMP Nurul Jadid untuk mencapai derajat kesehatan reproduksi yang optimal.

Usia remaja awal adalah masa yang tepat untuk diberikan informasi kesehatan mengenai Vulva Hygiene, dimana pada masa remaja merupakan masa penyerpurnaan perkembangan dari tahap-tahap sebelumnya (Csikszentimihalyi 2013), menurut Sarwono (2013), puncak perkembangan jiwa remaja ditandai dengan adanya proses perubahan dari kondisi entropy (isi kesadaran saling bertentangan) ke kondisi negentropy (isi kesadaran tersusun dengan baik). Maka dari itu penyuluhan kesehatan sangat penting untuk para remaja putri khususnya siswi SMP Nurul Jadid, agar remaja putri dapat mengetahui dan memelihara vulva secara baik dan benar serta meningkatkan kesadaran akan perilaku vulva hygiene (Basoa, 2009).

Menurut Ramaiah (2006), orang yang ada disekitar kita merupakan salah satu diantara komponen social yang ikut mempengaruhi sikap kita. Berdasarkan Niven, N(2002) diantara orang yang biasanya dianggap penting bagi individu adalah orang tua, orang yang status sosialnya lebih tinggi, teman sebaya, teman dekat, guru, teman kerja dll orang yang disekitar kit aini yang membentuk sikap seseorang. Selain itu juga menurut hananto,E (2009), apabila orang disekitar melakukan Tindakan yang positif, maka tanpa disadari orang tersebut akan melakukan Tindakan positif pula.

Hasil penelitian terdahulu yang dilakukan oleh Ervina (2011), mengemukakan bahwa perilaku remaja putri dalam merawat perineum saat menstruasi sebelum diberikan penyuluhan kesehatan mayoritas terdapat pada kategori cukup (75\%) dan sesudah diberikan penyuluhan terdapat pada kategori baik (100\%). Sehingga dapat disimpulkan bahwa ada perbedaan yang signifikan sebelum dan sesudah dilakuan penyuluhan kesehatan terhadap perilaku remaja putri dalam merawat perineum saat menstruasi. Penelitian yang dikukan oleh Punduh (2014), sebelum diberikan penyuluhan kesehatan reproduksi, remaja yang memiliki perilaku baik semula berjumlah 4 responden (20\%) dan setelah diberikan penyuluhan kesehatan reproduksi meningkat menjadi 20 responden (100\%), sedangkan remaja yang memiliki perilaku cukup semula 12 responden (60\%) menjadi 0 responden (0\%). Hasil uji statistik didapatkan nilai P.Value 0,00 yang berarti ada pengaruh penyuluhan kesehatan terhadap perilaku remaja. 
Penyuluhan yang dilakukan Hidayat (2020), terdapat pengaruh Promosi Kesehatan terhadap pengetahuan PHBS anggota pelaksana UKS sebelum dan sesudah di berikan Promosi Kesehatan dengan media Booklet, diperoleh $\mathrm{P}$ value $0.002<\alpha=0.05$

Secara umum, tujuan Pendidikan Kesehatan adalah mengubah perilaku individual atau masyarakat di bidang Kesehatan. Akan tetapi, perilaku mencakup hal yang luas sehingga perilaku perlu dikategorikan secara mendasar sehingga rumusan tujuan Pendidikan Kesehatan dapat di rincikan sebagai berikut.

1) Menjadikan Kesehatan sebagai sesuatu yang bernilai di masyarakat. Oleh sebab itu, Pendidikan Kesehatan bertanggung jawab mengarahkan cara-cara hidup sehat menjadi kebiasaan hidup masyarakat sehari-hari.

2) Menolong individu agar mampu secara mandiri atau berkelompok mengadakan kegiatan untuk mencapai tujuan hidup sehat.

3) Mendorong pengembangan dan penggunaan secara tepat sarana pelayanan Kesehatan yang ada. Adakalanya, pemanfaatan sarana pelayanan yang ada di lakukan secara berlebihan atau justru sebaliknya, kondisi sakit, tetapi tidak menggunakan sarana Kesehatan yang ada dengan semestinya (maulana, 2009).

Upaya agar masyarakat berprilaku atau mengadopsi prilaku Kesehatan dengan cara persuasi, bujukan, imbauan, ajakan, memberikan informasi, memberikan kesadaran, dan sebagainya,melalu kegiatan yang disebut Pendidikan atau promosi Kesehatan.

Dalam rangka pembinaaan dan peningkatan prilaku Kesehatan masyarakat, tampaknya pendekatan edukasi (Pendidikan Kesehatan) lebih cepat di bandingkan dengan pendekatan koersi. Dapat di simpulkan bahwa Pendidikan atau promosi Kesehatan mengupayakan agar perilaku individu, kelompok, atau masyarakat mempunyai pengaruh positif terhadap pemeliharaan dan peningkatan Kesehatan (notoadmodjo, 2007).

Pada pengabdia ini karakteristik usia responden ada pada rentang usia 1113 tahun, usia ini sudah masuk pada tahap operasi formal. Pada tahap ini, anak akan mulai berasumsi, dapat berfikir secara logis berdasarkan 
kemungkinan. Kemampuan untuk membandngkan dan membuat pemikiran secara abstrak serta mampu mengambil kesimpulan dari informasi yang didapat (Pertiwi, 2018)

\section{Kesimpulan}

Tingkat pengetahuan Siswi SMP Nurul Jadid sebelum diberikan penyuluhan kesehatan mempunyai tingkat Pengetahuan Rendah sebanyak 54 siswi (77\%). Setelah diberikan penyuluhan kesehatan Siswi SMP Nurul Jadid mempunyai tingkat Pengetahuan baik sebanyak 69 Siswi (99\%).

\section{Pengakuan}

Pada kesempatan ini dengan segala hormat kami mengucapkan terima kasih kepada

1. Ibu Kholisotin, S.Kep,Ns.,M.Kep. yang telah membimbing kami selama masa KKN dengan baik.

2. Kepada Guru dan Siswi SMP Nurul Jadid kelas VII yang telah berpartisipasi dalam mengikuti kegiatan penyuluhan kesehatan

3. Kepada semua pihak yang tidak bisa disebutkan satu persatu yang telah membantu jalannya penyuluhan kesehatan.

\section{Referensi}

Ayu. (2010). Cara Holistik dan Praktis Atasi Gangguan Khas Pada Kesehatan Wanita. Jakarta: Bhuana IImu Populer.

Bayang, A. (2016). Promo Konseling Kesehatan Reproduksi. (J. Manarisip, Ed.).Sulawesi Utara: BKKBN.

Boyke. (2008). Tanda Dan Gejala Kanker Mulut Rahim. http://www.pdpersi.co.id.

Basoa. (2009). Kesehatan Reproduksi Panduan Bagi Perempuan. Yogyakarta: Pustaka Belajar. 